\section{Collapsible washing lines: a strangulation hazard}

Collapsible rotary clothes lines may form a hazard to young children, as shown by the following case report.

\section{Case report}

An 18-month-old boy was admitted to hospital after being strangled accidentally in the dependent loops of a rotary washing line. The line had been left upright but its radial arms had been folded down. A few minutes after he had gone to play outside his mother had found him kneeling by the line with three strands of cord wound tightly around his neck (figure). $\mathrm{He}$ was unconscious and was not making any respiratory effort; peripheral pulses were not detectable. Initial resuscitation was performed by ambulance staff.

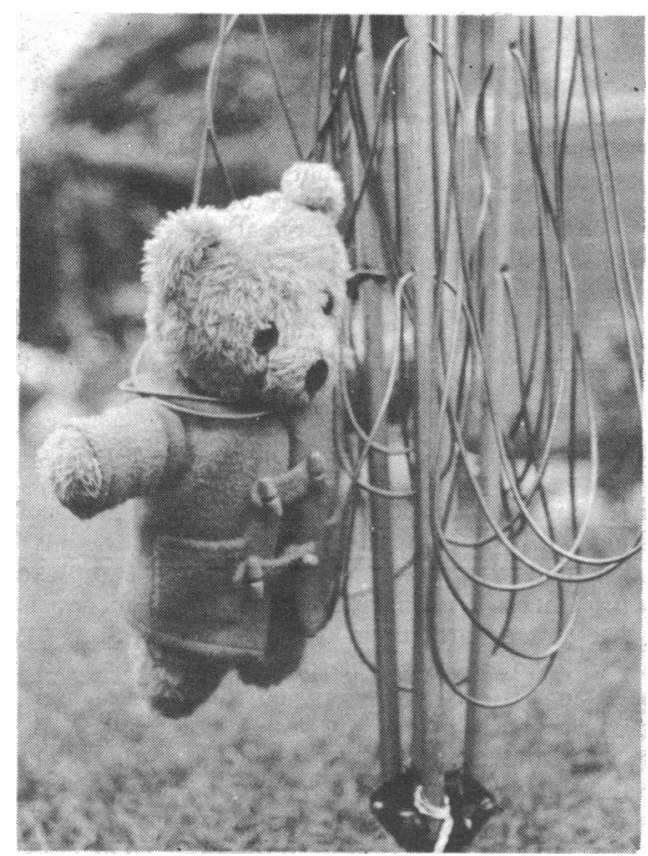

Washing line in collapsed position.

On arrival at hospital he was breathing spontaneously and had a normal cardiac rhythm. He had widely dilated pupils, was hypertonic, and had intermittent clonic convulsions. He was given oxygen, and metabolic acidosis was corrected. Fluids were restricted and dexamethasone was given for 24 hours. He recovered rapidly and was discharged two days after admission, having suffered no permanent neurological damage. While playing with the loops of the clothes line he had presumably become entangled and had been asphyxiated during his struggles to free himself.

\section{Comment}

Accidents are the commonest cause of death in children between the ages of 1 and 15 years in the United Kingdom. ${ }^{1}$ For every fatal accident there are many more that result in appreciable morbidity. From birth until the age of 3 or 4 years most accidents are likely to occur in or around the home. Recognising and preventing potential hazards to children in the home environment is essential in reducing mortality and morbidity from accidents in the early years of life.

Strangulation in children is a fairly uncommon form of fatal accident but is one that is more easily preventable. It may take diverse forms, as shown in a recent report from Seattle, ${ }^{2}$ which drew attention to hazards such as widely spaced slats or rails in cots, cords attached to pacifiers or articles of clothing and toys, window cords, and looped rope swings as potential and actual causes of strangulation. Although the Child Accident Prevention Committee in this country has not recorded similar accidents due to washing lines during the past three years, rotary clothes lines are used widely by families with young children and we wonder whether unreported incidents have occurred.
The most effective preventive measures are those that are simple and instituted easily, providing the hazard is recognised initially, but the potential danger of dependent loops of a rotary line may not occur readily to parents. The manufacturers of this particular washing line already indicate in their instruction leaflet that the line should be collapsed and removed to undercover storage when not in use. They now plan to include a further safety warning. Alternatively the line should be left in the extended position in which it is used.

${ }^{1}$ Jackson RH. Setting the scene. In: Jackson RH ed. Children, the environment and accidents. Tunbridge Wells: Pitman Medical Publishing Co Ltd, 1977:1-19.

${ }^{2}$ Feldman KW, Simms RJ. Strangulation in childhood: epidemiology and clinical course. Pediatrics 1980;65:1079-85.

(Accepted 18 February 1981)

Department of Child Health, Medical School, Queen's Medical Centre, Nottingham NG7 2UH

D ROBERTON, MD, FRACP, paediatric registrar

K ROOKWOOD, BMEDSCI, BM, paediatric senior house officer

N RUTTER, MD, MRCP, senior lecturer in child health

\section{Immune complex detection in arterial and venous blood: a preliminary study}

The detection of circulating immune complexes in serum has become widespread in clinical practice. Several infectious, immunologically mediated diseases have been associated with such complexes, ${ }^{1}$ and disease activity has been correlated with their presence. ${ }^{2}$ In some patients with active vasculitis and immunoglobulin deposition in vessels and glomeruli, however, no circulating immune complexes can be detected despite the use of several different techniques to assay them. We speculated, therefore, that in some of these patients pathogenic immune complexes circulate in the arterial blood and are deposited in the peripheral tissues. If that is so a negative venous sample cannot exclude an immune-complex-mediated disease. In this study we looked at paired arterial and venous samples from a heterogenous group of patients to determine whether arterial sampling might be helpful in finding circulating immune complexes not present in the venous blood.

\section{Patients, methods, and results}

Twenty-five samples of arterial (radial artery) and venous (cubital vein) blood were taken simultaneously from 23 patients. Circulating immune complexes were assayed by three different techniques: Clq binding, ${ }^{2}$ monoclonal rheumatoid factor binding, ${ }^{3}$ and conglutinin binding. ${ }^{4}$ Samples were tested in duplicate on two separate occasions. Only differences in binding greater than two standard errors were regarded as significant, and to be reported one of the two samples had to be above the normal range. The results were reported in $\mu \mathrm{g} / \mathrm{ml}$ equivalent of aggregated $\mathrm{IgG}^{2}$ to compare the assays. Antigenic complement components (C3-C4) and total complement haemolytic activity were measured according to the methods of Lachmann and Hobart. 5

There was no significant difference between arterial and venous blood for antigenic $\mathrm{C} 3$ and $\mathrm{C} 4$ concentrations and for $\mathrm{CH}_{50}$. Eight pairs of samples were negative for circulating immune complexes. Of the 17 that did contain immune complexes, seven had similar concentrations in both samples. Results in the remaining $\mathbf{1 0}$ are summarised in the table.

\section{Comment}

We observed significant differences in circulating immune complex concentrations in paired arterial and venous samples from several patients. In two, complexes were detected only in the arterial blood. Their presence would have been missed if we had relied only on venous samples. Circulating immune complex concentration in the venous circulation was higher in other patients, however, and in one complexes were found only in the venous blood.

In this preliminary study no particular trend was apparent, but the observed differences have to be explained by in-situ clearance, 
Concentrations of immune complexes in 10 pairs of samples obtained in eight patients

\begin{tabular}{|c|c|c|c|c|c|c|c|}
\hline \multirow{3}{*}{$\begin{array}{l}\text { Case } \\
\text { No }\end{array}$} & \multirow{3}{*}{ Disease } & \multicolumn{6}{|c|}{ Immune complex concentration ( $\mu \mathrm{g} / \mathrm{ml}$ equivalent aggregated $\mathrm{IgG}^{2}$ ) } \\
\hline & & \multicolumn{2}{|c|}{$\underset{\text { binding }}{\text { Clq }}$} & \multicolumn{2}{|c|}{$\begin{array}{l}\text { Monoclonal rheumatoid } \\
\text { factor binding }\end{array}$} & \multicolumn{2}{|c|}{$\begin{array}{l}\text { Conglutinin } \\
\text { binding }\end{array}$} \\
\hline & & Arterial & Venous & Arterial & Venous & Arterial & Venous \\
\hline \multirow{3}{*}{$\begin{array}{l}1 \\
2 \\
3 \\
\\
4 \\
5 \\
6 \\
7\end{array}$} & \multirow{3}{*}{$\begin{array}{l}\text { Active cutaneous vasculitis } \\
\text { Jejunoilial bypass and arthritis } \\
\text { Acute renal failure + cellulitis of right hand: } \\
\text { Samples from right arm } \\
\text { Samples from left arm } \\
\text { Subacute bacterial endocarditis } \\
\text { Systemic vasculitis } \\
\text { Focal glomerulonephritis and purpura } \\
\text { Hypereosinophilia during treatment: } \\
\text { First assay } \\
\text { Second assay } \\
\text { Acute Wegener's granulomatosis }\end{array}$} & $\mathbf{N}$ & $\begin{array}{l}15 \\
30\end{array}$ & $\mathbf{N}$ & $\begin{array}{l}\mathbf{N} \\
20\end{array}$ & $\begin{array}{l}\mathbf{N} \\
15\end{array}$ & $\begin{array}{l}15 \\
60\end{array}$ \\
\hline & & $\begin{array}{r}15 \\
100 \\
70 \\
25\end{array}$ & $\begin{array}{r}30 \\
15 \\
250 \\
100 \\
50\end{array}$ & $\begin{array}{l}N \\
60 \\
50 \\
20\end{array}$ & $\begin{array}{r}\mathbf{N} \\
\mathbf{N} \\
250 \\
110 \\
35\end{array}$ & $\begin{array}{c}N \\
40 \\
100\end{array}$ & $\begin{array}{r}30 \\
15 \\
\mathbf{N} \\
40 \\
110\end{array}$ \\
\hline & & $\begin{array}{c}\mathbf{N} \\
100 \\
30\end{array}$ & $\begin{array}{l}\mathbf{N} \\
\mathbf{N} \\
\mathbf{N}\end{array}$ & $\begin{array}{l}\mathrm{N}_{20}^{\mathrm{N}} \\
20\end{array}$ & $\begin{array}{l}\mathbf{N} \\
\mathbf{N} \\
\mathbf{N}\end{array}$ & $\begin{array}{l}20 \\
15 \\
15\end{array}$ & $\begin{array}{l}\mathbf{N} \\
\mathbf{N}\end{array}$ \\
\hline
\end{tabular}

$\mathrm{N}=$ Percentage binding in normal range.

formation, or alteration of circulating immune complexes. Further work along these lines may lead to a better understanding of the relation between circulating immune complexes and disease.

1 Zubler RH, Lambert PH. Immune complexes in clinical investigation. In: Thompson RA, ed. Recent advances in clinical immunology I. Edinburgh: Churchill Livingstone, 1977:125-47.

2 Pussell BA, Lockwood CM, Scott DM, Pinching AJ, Peters DK. Value of immune complex assays in diagnosis and management. Lancet 1978; ii :359-64.

${ }^{3}$ Halla JT, Volanakis JE, Hardin JG, Schrohenloher RE. Immune complex detection and complement activity in rheumatoid arthritis: a comparative study of a radioimmunoassay using monoclonal rheumatoid factor, gel diffusion techniques and C4 activity. Clin Exp Immunol 1978;34:226-34.

4 Macanovic M, Lachmann PJ. Conglutinin binding polyethylene glycol precipitation assay for immune complexes. Clin Exp Immunol 1979;38: 274-83.

55 Lachman PJ, Hobart MJ. Complement technology. In: Weir DM, ed. Handbook of experimental immunology. 3rd ed. Oxford: Blackwell, 1976: 5A.1.

(Accepted 16 February 1981)

Royal Postgraduate Medical School, Hammersmith Hospital, London W12 0HS

J A SCHIFFERLI, DR, research fellow

A DASH, scientific officer

D C SUTHERLAND, FRACP, registrar

D K PETERS, FRCP, director, department of medicine

\section{Giant-cell arteritis mimicking carcinoma of the breast}

Vasculitides such as polyarteritis are normally multisystem diseases, though the breast is rarely affected. Four such cases have been reported, ${ }^{1-4}$ but in only two was the breast lesion the dominant presenting feature. ${ }^{1-3}$ We describe a patient who presented with a lump in the breast that mimicked carcinoma but which was found to be a vasculitis of the giant-cell type.

\section{Case report}

A previously healthy 59-year-old woman presented with a two-week history of malaise and generalised aches and pains. She had a swollen, painful left ankle and was feverish. Blood and protein in the urine were attributed to a urinary tract infection. The main problem detected by her general practitioner was a lump in the right breast. This was hard and fixed to the deep tissues and to the skin. She was referred to a surgical unit with provisional diagnosis of carcinoma of the breast.

On examination the cardiovascular and respiratory systems were normal There was slight tenderness in the right hypochondrium, though the live was not palpable. The left ankle was swollen and painful. There was a firm irregular mass in the right breast at 2 o'clock measuring $4 \times 3 \mathrm{~cm}$. The nipple was retracted, and the patient reported that this was a new feature. There was a similar lump in the left breast, also fixed to the skin, and one or two nodes palpable in the right axilla. Bilateral breast carcinoma with spread to the right axilla was diagnosed. Systemic symptoms were attributed to metastatic spread of the disease.

Investigations showed normal full blood count and normal urea and electrolyte concentrations. Erythrocyte sedimentation rate was $98 \mathrm{~mm}$ in the first hour. The midstream specimen of urine was sterile but the presence of blood and protein was confirmed. Results of skeletal survey were normal, and a radiograph of the ankle showed soft-tissue swelling with no definite bony lesion. Liver function values were normal.

Under general anaesthesia the lump in the right breast was sampled for biopsy, along with two smaller lesions located at operation. The lesion in the left breast was also sampled and all specimens submitted for frozen-section examination. Histologically the specimens from both breasts were essentially similar and showed intense vasculitis affecting mainly medium-sized arteries but sparing the veins. The lesions varied from an acute pattern, with fibrinoid necrosis of the wall and a distinct infiltrate of polymorphs affecting all the coats, to a subacute form, in which chronic inflammatory cells, including giant cells, predominated (figure). This was diagnosed as a necrotising giant-cell arteritis, raising the possibility of a systemic collagen disease. There was no evidence of malignancy.

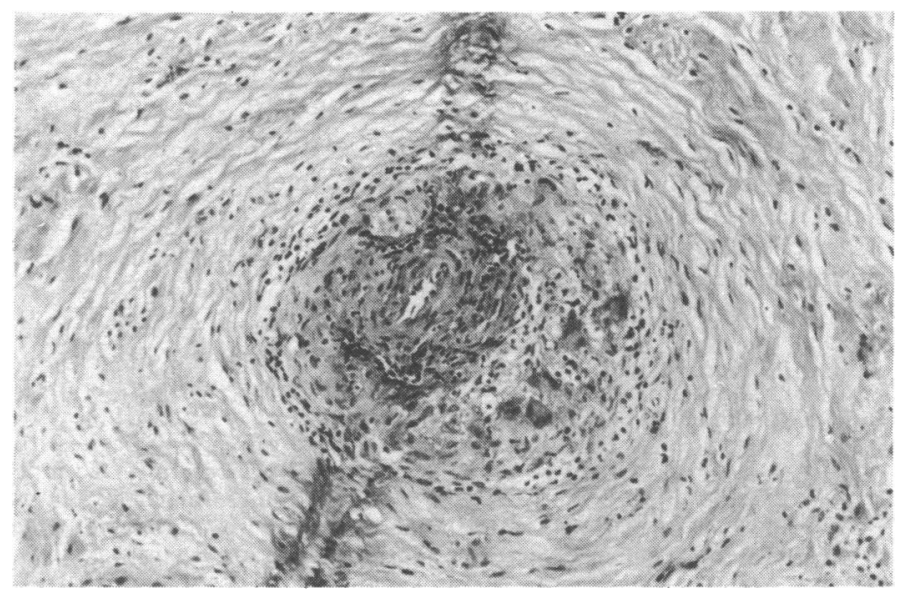

Section from breast showing vessel with inflammatory infiltrate and giant cells. Haematoxylin and eosin $\times 160$ (original magnification).

Titres against antinuclear factor were weakly positive on two occasions but subsequently remained negative. Results of plasma electrophoresis were normal, as was a screen for autoantibodies, including DNA-binding antibody. Hepatitis B antigen was not detected. Renal angiography and biopsy showed nothing abnormal. Hence further investigations were not helpful in defining the type of vasculitis. During the investigations it became apparent that the patient was improving spontaneously (increase in weight, fall in erythrocyte sedimentation rate, disappearance of systemic symptoms) and no treatment was given. Within a few months she was perfectly well with no new lesions. Erythrocyte sedimentation rate was normal, and urine analysis showed no blood or protein; she remained well 20 months later.

\section{Comment}

Arteritis is generally a multiorgan disease but lesions in the breast have only rarely been reported. ${ }^{1-4}$ In those reports the breast lesion was the dominant clinical feature in two of the cases. ${ }^{1-3}$ The other 